University of Louisville

ThinkIR: The University of Louisville's Institutional Repository

Electronic Theses and Dissertations

$5-2004$

\title{
A hundred visions and revisions : becoming a better actor.
}

Shawn M. Knight 1977-

University of Louisville

Follow this and additional works at: https://ir.library.louisville.edu/etd

\section{Recommended Citation}

Knight, Shawn M. 1977-, "A hundred visions and revisions : becoming a better actor." (2004). Electronic Theses and Dissertations. Paper 765.

https://doi.org/10.18297/etd/765

This Master's Thesis is brought to you for free and open access by ThinkIR: The University of Louisville's Institutional Repository. It has been accepted for inclusion in Electronic Theses and Dissertations by an authorized administrator of ThinkIR: The University of Louisville's Institutional Repository. This title appears here courtesy of the author, who has retained all other copyrights. For more information, please contact thinkir@louisville.edu. 


\title{
A HUNDRED VISIONS AND REVISIONS: BECOMING A BETTER ACTOR
}

\author{
By
}

Shawn M. Knight

B.A., Belmont University, 1999

M.A., Auburn University, 2001

\begin{abstract}
A Thesis
Submitted to the Faculty of the Graduate School of the University of Louisville In Partial Fulfillment of the Requirements For the Degree of
\end{abstract}

Master of Fine Arts

Department of Theatre Arts University of Louisville Louisville, KY

May 2004 
Copyright 2004 by Shawn M. Knight

All rights reserved 


\title{
A HUNDRED VISIONS AND REVISIONS:
}

BECOMING A BETTER ACTOR

\author{
By
}

Shawn M. Knight

B.A., Belmont University, 1999

M.A., Auburn University, 2001

A Thesis Approved on

April 13, 2004

by the following Thesis Committee:

Thesis Director, Dr. Russell Vandenbroucke

Dr. Albert J. Harris

Dr. Philip G. Laemmle 


\section{ACKNOWLEDGEMENTS}

Many thanks to Russell Vandenbroucke for his careful and caring reviews of and discussions about this thesis and many aspects of theatre over the past three years, to Dr. Harris and Dr. Laemele for their assistance and interest in this project, to my family, to my teachers, and to my classmates Kia Fisher and Stacey Smith for their love and support. I truly believe that we have been an exceptional class, that we will not be forgotten, and that we never could have achieved our successes here in Louisville without each other. 


\section{ABSTRACT \\ A HUNDRED VISIONS AND REVISIONS: BECOMING A BETTER ACTOR \\ Shawn M. Knight}

April 13, 2004

This thesis considers my preparation for and performance in The Night Thoreau Spent in Jail. Through four themed chapters (ego, intellect, energy, and fear), I explore strengths of my acting that have become weaknesses. I consider their sources and how they have become liabilities to me as an actor. After examining these in detail, I use the conclusion of the thesis to propose ways to maintain these strengths as strengths by using them to counteract and support each other, thus allowing me to move toward a greater goal—that of transforming more thoroughly into markedly different characters onstage. The epilogue describes my first attempt to apply the proposals made in my conclusion to my acting. 


\section{TABLE OF CONTENTS}

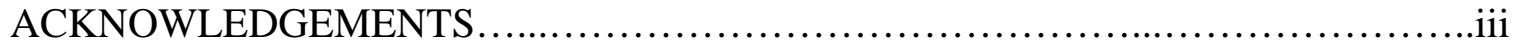

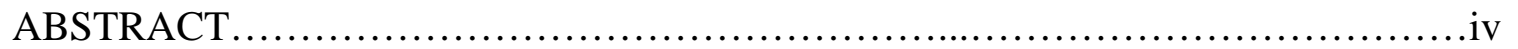

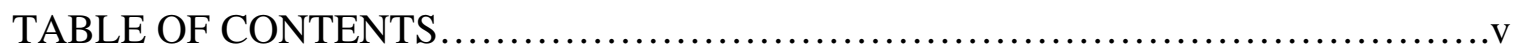

The Introductory Case: Black and White.........................................

Case \#1, The Super-Ego....................................................4

Case \#2: Intellect........................................................11

Case \#3: Energy....................................................... 17

Case \#4: Fear.............................................................24

Conclusion: A Balanced Palate.................................................30

Epilogue: Four Months Later............................................. 35

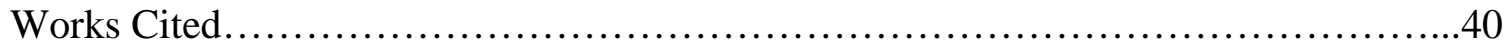

CURRICULUM VITAE.....................................................41 


\section{The Introductory Case: Black and White}

“There are no wrong choices in theatre; some are just better than others.” My undergraduate acting teacher, Laura Skaug-Green, often reminded her students of this, half in jest, half quite seriously. It became a joke, a mantra, a guide to criticism and rehearsal. Most importantly, though, it became a reminder that every moment of creation and rehearsal and performance is an opportunity to make choices and to explore alternatives. Such exploration is difficult for me. I tend to see things in black and white terms - this is right, that is wrong; this is good, that is bad. I make decisions, and I tend to hold to them, defending them from various critiques and constructive comments rather than assessing the value of the individual critical notes. Though I have grown much more open to criticism and learned that a shift in choice or idea most often does not destroy my artistic vision, but rather enhances it, I still find myself fighting my urge to lock into a choice early and maintain it.

For some, this insistence on holding chosen ground might be a positive trait, but for me, it is a liability as an actor. When I plan and make decisions fast and rigidly, I do not allow for discoveries. I do not give myself the time to let myself be unsure; I see an obstacle and the solution, and I set about putting the solution to work. And when I am done, I am done, despite the fact that in reality, there are more questions than answers. But I have become very good at intellectualizing the questions away, covering them with 
convoluted explanations that fit within my narrow path and mindset and using a sort of sleight of hand and disorienting energy to hide the flaws from others, often even from myself.

This does all kinds of disservices to all kinds of people-my audiences, my directors, my fellow cast members, the playwrights, and, not the least, myself. I am too good of a performer for that, and I know I am too good. I have abilities and talents that I can use to create new and exciting things, but I often settle for the easiest and the obvious, not as a conscious choice, but rather as a safe one. As a result, I often show an unintended lack of trust toward my fellow cast members and director. By not allowing myself to trust as we discover new and different possibilities in a script or a character, I might ultimately weaken the ensemble by making decisions ahead of time, only altering them enough to encompass direction in a way that will still allow the character to fit safely into my initial conception of the way the role should be played.

How can this habit be broken? During the process of performing my thesis role and writing about that process, I have discovered that my acting strengths may sometimes be weaknesses that encourage me to avoid the painstaking discoveries crucial to theatre work that is alive and vibrant. But these strengths are strengths to begin with for a reason, so how can strengths ultimately be weaknesses, and if this hypothesis is correct, how can I turn them back into strengths?

This is the central idea to be explored in this thesis. In an attempt to teach myself to prosper within a new mode of thinking, I propose to write several short chapters about various issues concerning my acting. Each chapter will deal with what I consider to be a weakness, including some strengths that I am now realizing are weaknesses, as I discover 
that they have become crutches that get in the way of new work. Within each chapter, I will introduce an issue, consider its sources and its effects on my acting experiences, and then propose a way to address that issue. I will attempt not to judge in this process; rather I will evaluate times when these acting issues may be more or less useful, recognizing that "there are no wrong choices in theatre; some are just better than others." Then, after I feel I have considered the traits that played particular roles in my thesis production, I will conclude by assessing my assessments and propose ways to put my new discoveries into action on future projects.

In some ways, the planning of the last paragraph already negates what I have proposed to do, which is a more free-flowing approach to creating this work. But more accurately, it reflects what I believe I need to do—consider an issue with my acting, reflect on how it affects my work, then propose a way to address that issue-in order to move to the next step in my growth as an actor. In this first case, I have considered my tendency to view things in black and white terms. I have noted how this creates an unintended disrespect toward collaborators. I have also proposed that one way to overcome this as a weakness is to attempt to have a wider view of things, less rigid and planned, which I propose to do as I write this thesis. Only when I reach my conclusion, if the path still heads in the imagined direction, I will assess how successful I was with this approach. 


\section{Case \#1: The Super-Ego}

On October 29, 2003, I opened in The Night Thoreau Spent in Jail, by Robert E. Lee and Jerome Lawrence, playing Henry David Thoreau, at the University of Louisville Playhouse, directed by University of Louisville Theatre Arts professor, Dr. Bert Harris. This was my thesis role. I officially performed the role six times, and the show closed on November 2, 2003.

Case \#1 is about what some consider my greatest weakness as an actor-my Super-Ego. Freud's term superego refers to a person's internal conscience, the good/bad gauge, commonly imagined as the devil and the angel on a shoulder. This is not the way in which I use the term. Quite simply, I mean vanity, ego, pride-any term to express feelings of superiority. I call it "Super-Ego” merely because it often feels deeper and more insidious than what many might consider the typical ego of an actor. I sometimes doubt that my ego is any larger than that of the majority of actors, but for the purposes of this thesis, placing qualities under a microscope and examining them at their deepest level ultimately makes them seem their worst while simultaneously revealing new aspects about them. I write of this not without a great deal of embarrassment, but if I am to grow as an artist, I must recognize the tendency to value myself too highly. Professor Jim Tompkins (University of Louisville movement professor) reminds us each semester, “Be 
not proud of your success nor sorrowful over your defeat.” Easy enough to say, but for some actors like me, the ego gets in the way.

Consider a portion of my pre-production attempted thesis writing. The following was written before I had begun rehearsals, but it may still offer some useful insight:

I am a fine actor. And by that, I mean that I am decent. I communicate well. I comprehend and understand passages of plays, can speak them intelligently after having made decisions about them, and maintain an interesting stage presence. I make these claims not so much to brag about my abilities as to begin an assessment of my acting strengths that will lead to a recognition and assessment of my acting weaknesses that will in turn lead to the subject of this thesis. Clearly stated, I feel that I could be a more successful actor if I spent more time exploring (physically, vocally, mentally, and emotionally) whatever text lies before me and challenging myself continually to find new things in the play and to give those alternative choices more serious consideration as I create a character. I recognize that this is a very large goal and could indeed lead to a very vague thesis, but I see this statement as an umbrella, under which several more specific and focused goals and claims are huddling, trying to keep out of sight of the egotistic actor who hopes to view them in full light and address them in the following pages.

Upon reading this after my thesis performances were completed, I note several key phrases. I write that "I make these claims not so much to brag about my abilities," which is true, but the fact that I need to make an explanatory addendum is curious. Likewise, the final sentence about the goals and claims that are "trying to keep out of sight of the egotistic actor who hopes to view them in full light” seems less than sincere as I review my work. All the half-serious, appeasing comments about my ego aside, my ego can be a problem.

My ego surrounds my sense of my own intelligence more so than anything else. For some actors, their ego is fed by their looks, their physical abilities, or their musical abilities; for me, it is my intelligence. I have always prided myself on my high grades in school. I pride myself on being well-read, informed, and knowledgeable about a wide 
variety of topics. This intelligence leads me to make strong choices about my acting work and the character I am creating. But the issue of intelligence per se is another chapter's case; I must consider how my ego is affected by this intelligence, and to put it bluntly, it can make me “deaf to sound advice."1

As some professors at the University of Louisville will recognize, I have a tendency to argue first and to think later. Professor Tompkins observed this trait in my first semester and commented upon it in my evaluation at the end of the semester, as did Rinda Frye (University of Louisville Theatre Arts voice and acting professor), who (however) actually found it a useful and exciting trait. And Department Chair Russ Vandenbroucke has observed that it is often difficult to get the last word with me, which I imagine is attributable to this same "argue first, think later" approach. I suspect that this approach might result from the power of my ego.

Some of the most difficult moments for me to grasp and act in Thoreau were Thoreau's flirtations with both Ellen and Lydian. The first several times I read the script, I saw quite clearly his attraction to Lydian, and, unable to unify this with his love of Ellen, I diminished the importance and sincerity of his love for Ellen, dismissing it almost as true love for his brother. I saw the entire boat ride as Thoreau's bumbling attempt to declare a love of which he is unsure, already knowing that it would end disastrously and that he would find himself trying to woo Ellen for his brother. To that end, I also never saw the flirting involved with Ellen during their introductory scene as Thoreau is teaching his class. I interpreted all the personal lines he delivers to her solely as larger, more universal lessons that he attempts to teach his pupils. They are this, but they are also much more.

\footnotetext{
${ }^{1}$ Creon in Sophocles's Antigone, adapted by Steve Schultz
} 
I think I failed to notice these because I did not want to see them. I had never before performed a particularly romantic role or scene, and my nerves rose at the thought. What, after all, can hurt an ego more than a failed romantic attraction? And if I cannot even fabricate one (though many would quibble with the idea that an actor should ever fabricate a feeling) on stage, what kind of actor am I? So I naturally interpreted the scenes to allow for performances that would make me most comfortable as Henry: Henry and I can both teach well; we can both woo for others. But I personally fear both risking rejection as a suitor and failing to create a believable romantic scene. ${ }^{2}$ To this end, I invested a great deal of time avoiding the romance of the scenes with Ellen. The later romance of Lydian would come more naturally for me because I recognize that, as a character, Thoreau knows Lydian is forbidden and that there is no chance of success, so he imagines there is less at stake. This recognition allowed me to pursue Thoreau's goals in these scenes more confidently because he will indeed fail, and this is not a reflection on me.

As we began rehearsals, the romance with Ellen became more obvious, and though I could no longer avoid it, I continued to do just that. At one rehearsal, Dr. Harris directed me to woo Ellen away from John, or more specifically, get him away from her; it was clear that Thoreau would never succeed with his brother present. I had great difficulty doing this because of my ego. I had already decided how this scene should be played. Thoreau should be so engrossed in his grass-watching that he practically forgets Ellen is there, and he is certainly not concerned about his brother. When Dr. Harris

\footnotetext{
${ }^{2}$ In retrospect, a wise way to approach this personal dilemma might have been to imbue Thoreau with these same fears. Certainly, the text would support such a choice, and I might have hinted at this in my performance. Still, if I had more thoroughly committed to such a choice, the scenes with Ellen might have exhibited an even truer sense of life.
} 
directed me to turn my concentration and focus on them, I balked. I asked questions, I argued a bit (although since I had already learned to trust Dr. Harris as a director while working on The Glass Menagerie, I did less of this than I might have), and I pouted. Yes, I pouted. I hope it was not too noticeable. Ultimately, though, I made the shift he was looking for. It took a few rehearsals, but I did.

What a waste of time! Why would this take a few rehearsals? Maybe to most of the people in the room, it did not seem to take that long, but it did because even as I was doing as directed, I continued to fight it internally, to find ways to play the action without meaning it. Soon, I realized that the scene was stronger for the adjustment, but I was now the weak link in the scene. I was the one not committing; I was the one not working as an actor. Much could be written positively about such a slow evolution in my work: I was protecting my center, my self, and my choices; I was taking the time to discover the truth of that journey; I was exploring how this shift influences the rest of the play. All that admitted, though, I feel there was another explanation. My ego had gotten in the way and was continuing to get in the way. And I had to let that go.

So I did. And what resulted were scenes like none I have ever played, romantic scenes that worked every night and that I often heard cited by different audience members as some of the show's strongest scenes, particularly the boat scene with Ellen. By letting go of my pre-planned conceptions and, thus, my ego, I was able to find a deeper level of human connection within the script. What resulted was a deeper level of human connection on the stage, both between characters and actors. I developed a deeper respect for my colleagues. No matter how strong my acting skills are, I find myself constantly jealous of those around me, always worrying (as I noted before) that I am the 
weak link in the scene or the production. As soon as I moved beyond the roadblock of my ego, I began to appreciate the various talents around me more fully, and I began to use those talents to my advantage and to share my talents to help others. I could more fully commit to living in the moment. There was a sense of freedom and true collaboration that my pre-planned, ego-based approach was not previously allowing. I remember the evening I first felt these new successes, because I left the rehearsal and cried at all the wasted time.

I make the experience sound truly transforming and monumental, and it was, but it is an experience that I will constantly have to remind myself to seek. At present, I am preparing for my first role in a play since Thoreau, and every time I memorize a line, I remind myself that I cannot make all the decisions about my character and my lines right now. In some ways, this issue of decisions might better be addressed in the chapter on intellect, but I feel strongly that if intellect were the only thing involved in these decisions, I would be more willing to alter them as new alternatives and evidence is discovered during rehearsals. Instead, the thing that blocks my growth as an actor in a role and a production, the thing that prevents me from truly doing the most alive, complex work that I am capable of is ego, the too self-assured ego that inhibits my acceptance of new ideas and my application of them to my work, simply because they do not mesh with my original conceptions.

The solution? I do not know. I was able to get around my ego in Thoreau because of my ego. As the lead in Thoreau, I wanted to be outstanding, so my ego drove me to do the things that would aid my achievement of this goal. So the solution would seem to be to want to be as good as possible always, which leads to a dilemma. I have 
never not wanted to be as good as possible. Where is the difference? Part of what made it possible to do some different things in Thoreau was the trust I felt for director and cast, a trust that is a luxury that I will not have every time I act. My challenge becomes how to cultivate that trust with strangers in a short period of time. When I performed in a Shakespeare festival in Greenville, NC, this past summer, I did not feel that trust, and that environment is one I will likely encounter again. Part of what I learned from that experience is to avoid the trap of comparison. I was cast in the role I was cast in because the director felt no one else could do it better. It does not matter that the role is not the lead, nor that I may feel the leads are not as strong as I would be. What matters is that everyone in a rehearsal room brings different skills, different talents, and different challenges. The sooner I can recognize that diversity and appreciate it, the sooner I can move beyond the limitations forced upon me by my ego.

This is what I discovered in Thoreau: the moments of struggle and doubt were a waste of my time. I trusted the people around me, and if shifts in my work had not succeeded, we all would have known that. We all would have recognized that there were stronger choices available to us, and we all would have altered our work and approaches again and again until the work improved. I must constantly remind myself both to hold and to release my ego. I feel strongly that all actors must maintain a modicum of ego, or their work can disappear, squashed by the demands of a dictator-director. However, to hold it stubbornly when the environment is clearly a nurturing one filled with people who want to create the best work possible is a waste of valuable time and energy. 


\section{Case \#2: Intellect}

The fist play I ever performed in was Aladdin. I played Aladdin. It was the final semester of my senior year at Houston County High School. I was cast because I was smart—because I could read, comprehend, and speak clearly and intelligently, not because I necessarily had any acting ability. None of us did. ${ }^{3}$ I suspect it was the first production (and likely the only one) for most of the cast. Already one of my most useful talents and strengths as an actor had surfaced —my intellect. By virtue of it, I was given the lead role in the annual senior play. The experience was wonderful. The show only ran one night, but the audience seemed to enjoy it, and (though I forgot a key line at a crucial moment, which the on-stage "narrator" had to give me) I felt my work had been a success. The play was not a deeply emotional tour-de-force for an actor, but my intellect allowed me to make strong choices for my character.

Having recently made the claim that my ego is born from my intellect and my pride over that intelligence, I now want to delve into that intellect, see just how massive it is or is not and just how useful it is or is not to me as an actor. As the example above indicates, my intellectual powers are what opened the door to the world of theatre for me, and intelligence is often listed as one of the tools of an actor, right up there with a voice and body. So if intellect is so important to actors, why am I considering it as one of my weaknesses? The answer is simple: many people have indicated it as such and warned

\footnotetext{
${ }^{3}$ I am pleased to clarify that Houston County High School now has a nice auditorium, theatre classes, and several productions a year.
} 
that it may hold me back and prevent me from creating truly alive and unique work on the stage. I am not convinced of this, but enough people have told me this, that I am growing to consider it more seriously.

In preparing for Thoreau, I used my academic skills to research the man and the writer—Henry David Thoreau. I read both Walden and "Civil Disobedience," as well as a biography on Thoreau ${ }^{4}$. These were quite helpful, but surprisingly to me, I found Walden and "Civil Disobedience” more helpful than the biography. Perhaps this should not have surprised me, but it did. I thought I was researching who this man was, what he looked like, acted like, what others thought of him, so I could create some sort of duplicate of Thoreau on stage. Instead, what became important was the humanity of Thoreau, his passions, his desires, his certainties, and his questions. His beliefs were strongly and passionately stated in his writings, yet there was an underlying gentleness and compassion I had not expected, nor remembered from my previous readings of Thoreau. This gentle fire intrigued me because I had already noted the dualities present in Thoreau. In fact, very early on, I had imagined that my thesis would be about the difficulty of portraying a character filled with contrasts.

When it came time to rehearse, however, the contrasts became the easiest part of portraying Thoreau. I understood them. I understood this man who wanted the world to be just and perfect and did not know how to make it so. I saw these frustrations and struggles, and I identified with them; they naturally brought about a living, breathing character, one who went beyond the potentially stuffy historical figure so many high school and college students have met. Every night of rehearsal and of performance, I

\footnotetext{
${ }^{4}$ Harding, Walter. The Days of Henry Thoreau. New York: Alfred A. Knopf, 1965.
} 
found myself sink fairly easily into Thoreau, and I got there through his contrasts, through the confusions, not through the certainties.

My performance evaluations by the faculty, however, suggest otherwise. Deanna Thomas (University of Louisville Theatre Arts professor) asked, “Are there struggles in the character? I did not see them.”5 And Dr. Frye commented, "Because he’s a good musical theatre performer and knows what works there, he sometimes relies on what he knows will work.” When I spoke with her about this comment, she clarified:

I remember realizing in the late '70's that I was constructing characters who knew too much - that after I'd worked out their central actions, their superobjectives, etc., that I'd left no room for the unknown, for the surprises that make the work come alive and that let the audience into the puzzle of life in ways that implicate them in the action. ... So, I stepped back and paid more attention to what the other characters were doing and saying, played with the notion that sometimes we respond to one another ... . in ways that we don't fully understand—because our buttons are pushed, or out of habit. That, in turn, let me step back and look at the play as a whole.... This then led to a radical change in my work-instead of having a simple superobjective that I fulfilled each night, I began my performance each night with a question — one of those big ones - that I tried to answer during the course of the evening, by playing the play.... I liked your performance in Thoreau, but my only quibble about it was that Thoreau knew too much-he always seemed to know he was right, knew what action to take to move the show along, etc. I felt he needed more moments of indecision and realization, which would have given more shape to his action, made it less predictable and more powerful. Perhaps. I'm not certain the script allows for much of this, but I think it would.

And why would not Thoreau know he was right? After all, I did. I knew what Thoreau's actions would lead to, and I knew that they would ultimately lead to positive things for the character; his choices and the consequences that ensued would always lead Thoreau where he wanted to end up, and the play would move in the right direction, spreading Thoreau's message and revealing the intentions of the authors, director, and performers.

\footnotetext{
${ }^{5}$ Further clarification of this comment reveals that Dr. Thomas was wondering more about Thoreau's political choices, than the character I had created on stage; the comment might still apply, however, and certainly is worth considering in this case.
} 
It would seem, though, that in the process I lost something. What initially struck me as impossible to portray, Thoreau's uncertainties, his contrasts and dualities, haunts me now. I did not portray that which I felt most strongly about. Where had that gone? I begin every rehearsal process with an idealized, fantastical view of how wonderfully I would play my role and how deftly I would arrive there (as admitted in Case \#1: The Super-Ego), but these dreams vanished once the real work began. I met a conundrum. Why is that? I stand by my early claims in the original introduction: "I communicate well. I comprehend and understand passages of plays, can speak them intelligently after having made decisions about them, and maintain an interesting stage presence.” If this is so, then why do I find my initial hopes dwindle as I actually create the role? I have the tools and the knowledge to make the role what I see it to be. And while every actor and director can always make stronger choices somewhere in the work and analyze the text in a different way every time they delve into it, I do not think my difficulties lie most heavily in interpretation.

Yet I believe that interpretation is the path by which I arrive at my goal: "Clearly stated, I feel that I could be a more successful actor if I spent more time exploring (physically, vocally, mentally, and emotionally) whatever text lies before me and challenging myself continually to find new things in the play and to give those alternative choices more serious consideration as I create a character.” Interpretation may be a path, but I wonder if it is the path. I wonder if intuition might be a stronger guide, or if something is wrong with my interpretive skills, or if I meet a disconnect between interpretation and performance. More importantly, though, I ask this question: if my portrayal of Thoreau was a success (and I believe it was), why I am seeking for a way to 
improve it? As I read The Night Thoreau Spent in Jail multiple times this summer, I created images of my amazing success in the role. I would blow audiences away. I would give them things they had never seen from me. As I performed the role each night, I felt that I was doing just that. Once the show was over, I felt the work had been successful. And then I received my end-of-semester evaluation.

The comments on this evaluation brought me back to reality from the fantastical world I had imagined, and I feel that this discussion of them belongs in this chapter on intellect, because somewhere between my ego and my intellect and the actual performances lies the problem. Dr. Frye proposes one possibility:

You are a problem solver and can come up with good, energetic solutions quickly - but the first few solutions aren't always the best. You would do well to explore more before coming up with answers, and maybe to embrace that awful feeling of not knowing, to see where that leads you. And, in order to do this, you must find your own personal techniques for delaying some of your artistic choices....

Were I to come to rehearsal each day and force myself to try something different, I may discover things that I might otherwise have overlooked. These things, whether they be physical or verbal choices, internal, emotional responses, or a deeper understanding of the text, might lead in turn to a fuller, richer, more alive performance, a performance where I do not always know what will happen next. This sense of not knowing would read to an audience as if my character were truly living, trying things, and experiencing the results. The biggest problem with this option for me is that it relies too heavily on my intellect again. If I force myself to have new reactions and attempt new choices, I force myself to make these choices, an intellectual process that merely interferes with my attempt to turn off my intellectual process. The forced choices and actions would also be fake, for I know that I would be concentrating more heavily on 
these new pieces than focusing on the moment of the play. As a result, the "new choices" would lead to even more predictable moments.

I must remind myself that this is what rehearsals are for. If I allow myself the vulnerability and spontaneity to release control and if I let go of the sense that all rehearsals must be "right" and must lead toward exactly what I will do in the production, I will discover moments that will make the production stronger for the searching, for the not knowing. So a possible solution to the trap of intellect is to embrace my questions, my lack of answers, and my uncertainties about both the role and my abilities. By doing that, I may discover that both the role and my abilities are richer than I had imagined. 


\section{Case \#3: Energy}

My appetite whetted by my high school experiences in Aladdin and with a taste of theatre and the vast opportunities available on a college campus before me, I decided to visit the theatre department at Belmont University, where I signed up for a theatre orientation class, a class designed to introduce interested students to theatre as they completed sixty hours of work in the theatre. As the last production of the semester approached, I had only completed eight hours. I knew that I would be doing a great deal of work on this production, so I decided to audition for it, thinking I might be able to enjoy acting again as I simultaneously completed my theatre orientation hours.

Laura Skaug-Green cast me in On the Verge at the end of my freshman year at Belmont, having decided to break up the one male role in the show into several smaller ones. She comments on my audition: "He was a freshman and full of energy. I thought he had a great look and wanted to figure out a way to use him in the show.... I ended up casting him as Gus, a bubbly teenager (Shawn will remember the comparison to a puppy dog) and the baby yeti." So my first official role in what I consider a "real” play was earned by my energy. Energy has always been a strong suit for me, and I think this has a great deal to do with my ability "to deliver" on stage, as was observed on my evaluation for Thoreau. However, I am discovering that my energy can be a pitfall. Energy can sell 
a show, but it may also disguise weaknesses in acting. Dr. Frye clarifies her comments on my evaluation sheet:

I do recall ... saying something like, "he sometimes mistakes theatrical energy for real action, which involves more reaction” ... . what I meant was your tendency to "do something" with energy (not a bad trait in an actor), when perhaps you'd better suit the role and yourself by digging a little deeper into the situation, by responding and listening, by "not knowing" what response to have. .. .Y You are a problem solver and can come up with good, energetic solutions quickly — but the first few solutions aren't always the best. . . . This isn't just a musical comedy thing, but often musical comedy performers fall into this trap-an easy one when you have a wonderfully emotive song to sell to the audience every few minutes.

Part of me understands this comment, and part of me, even after her clarifications, does

not. Since my first role at Belmont, which I was given based mostly on my energy, I have noticed that I do have a stage presence, an energy that, at least as I assess it, both grabs and holds the attention of the audience and intrigues my acting partners, making it a more lively and enjoyable experience to work on a play with me. I pride myself on this energy and how far it can take me, but it can be a trap.

I suppose in some sense, my energy can combine with my intellect to create a potentially dangerous drive, a drive that pushes forward always. This eternally forwarddriven energy does not allow for a down moment or a backward moment along a path. Therefore, as my energy drives forward, guided by the intellect that has already interpreted the role, I rarely look back, see the ground I have covered, note the rocky spots in the path, the missed opportunities, and take the moment to reconsider. This is not to say that I ignore direction; I do not. I believe I take direction well, asking questions that help me to understand what the director envisions and how the work I am doing meshes or does not mesh with that vision. Then, I feel I am capable of absorbing the director's view into my own. 
That may be where I get into a bit of trouble. If I really do absorb the director's view into my own, rather than adjust my work to fit into the director's view, might there be a problem? And might the energy that I pride myself on drive me forward so blindly that I do not see this problem? In general, I do not feel that any of the work I have ever done has been disastrous, so I assume that I am pretty good at meshing director vision and personal interpretation. Still, how can I be more open to outside stimuli without sacrificing the forward drive and energy that can shine on stage?

During the first week of rehearsals for Thoreau, Dr. Harris reminded the cast constantly (and especially me) not to act. He did not want to see performances; he wanted to see people interacting honestly. This was extremely difficult for me. Professor Vandenbroucke has pointed out that portions of my performance in bee-luther-hatchee changed relatively little from the read-throughs to the final product, so clearly this is a habit of mine, to go in full-throttle, performing assuredly from day one. Dr. Harris was very insistent that I resist this. Similarly, he cautioned me not to begin memorizing lines before rehearsals began. This terrified me, and I was certain that once rehearsals arrived, I would find that I had no time to memorize my lines. Still, I did as he said and found that I did indeed have the time, and the lines were easier to memorize. His request was a reasonable one, designed to create maximum flexibility in me, as was the direction not to act as we began rehearsals. By forcing me to avoid decision-making as long as possible, Dr. Harris was creating an environment for a real character to develop, a character who could discover things, just as the actor discovered things each evening in rehearsal.

I found the process of resisting the desire to act very difficult. My drive to get to a product and solidify was high, and the imagined result was very taunting. Still, I 
attempted to avoid acting. I was more successful at this that I had imagined I could be, but it also became obvious to me when I was most successful—usually with Ben Owens, who played the role of my cellmate, Bailey. Why? This strikes me as an important question with several revealing answers, two of which seem extremely important to this thesis: I trusted Ben, and I could easily talk with him, not to him or at him, but with him.

Trust has previously been discussed in this thesis briefly, and it has been the minor subject of some class discussions. My ego and intellect often lead me astray and convince me that I am responsible for every scene, when in reality I am, of course, not. When rehearsing the scenes with Ben as Bailey, I found it easier not to act, but rather just allow the conversations that we had to be what they were. As a result, these scenes felt the most natural and the most certain. Not "certain" in the sense of completely tidy and perfected, but "certain" in the sense that I was confident that we were both focused on each other, a focus that allowed for greater flexibility in line delivery, blocking, and character relationships. This flexibility created a freedom that made the connection between Bailey and Thoreau just as strong as the connection between Ben and me, and just as comfortable. It was easy, in the scenes with Bailey, simply to talk with him. In scenes with Bailey, I never felt that Thoreau was trying to perform, as I felt he did in front of other townspeople—-particularly Ellen, Deacon Ball, and his students. And since Thoreau was not trying to perform, I never felt the need to do so.

How can this feeling translate into larger moments in the play? Certainly, I can reassess my interpretation of Thoreau as a performer. Thoreau was a shy and quiet man until riled, and it likely took more for Thoreau to fall into "performative" mode. I believe I needed to struggle more deftly in order to balance his performances with the reality of 
his moments; his performances, after all, would be done for a reason, and a clearer conception of that reason would strengthen the scene. Such possibilities do not require the dispersion of focused energy; rather, they demand a momentary braking in order to make sure I have not missed a side road I wanted to travel.

I missed several of those roads, and now I know how to find them more deftly. Dr. Frye would call it "embracing the not knowing;” I call it "cutting the bullshit," and Dr. Harris was excellent at calling me on this. Thanks to his expert eyes and ears, I learned to police myself when I fell into this energy-related trap, the trap that lures me into thinking that if the scene is going well because of the forward momentum building and pulling the scene along, the individual moments do not fully matter. During rehearsals, Dr. Harris would naturally stop us and ask us questions about the scene, about character relationships, or about our acting choices. Almost half the time he would ask me a question about a choice, I would have to admit that I did not have an answer. And then I would have to find one. Naturally, when I clarified a choice (or, to be more precise, made one), the scene grew stronger, both for me and the work I was doing and for the actors around me. Whenever Dr. Harris asked me a question and I discovered I had no answer, I wondered why I had no answer. Indeed, I wondered why I had failed to ask myself questions about that segment of the text.

Usually my answer involved acknowledging the blind progress I was making on a scene. If the scene seemed to move along, I believed it was working well, so I failed to see the hole in the work; my energy pushed me forward to perfecting the scene, without allowing me to see that it was not ready for "perfection." How had my intellect and preparatory work and planning missed this? Energy. I was too busy seeing the big 
picture that I missed the snapshots. But even the big picture was inaccurate as I made new and clear choices, for every minor decision affected the big picture and made the play stronger and clearer and the character more human.

However, even this recognition was not fool-proof and often lead to another trap-that of leaping to a decision and a conclusion without giving myself the time to think about it. I remember a moment at Belmont, rehearsing for 1940s Radio Hour, when Ms. Skaug, my director, asked me a question about my character that I could not answer. I made one up. It was not a very good one, and I felt stupid, so I vowed always to have an answer, to know my character and the situation well enough to have an answer ready for any question asked. Oddly enough, no real person I know is like that. I could ask anyone a question that would make him or her stop and think for a moment. Why, then, must my characters be so certain? Can they simply not know? Why do I submit to the energy and drive that force me to push beyond moments of thought? And how does that affect my fellow actors?

On one of our first nights rehearsing in the Playhouse, I was extremely tired, and it showed in my performance, and (as a result) the whole play. After the rehearsal, which was quite heinous and disturbing, Dr. Harris lectured us on our failure for the evening. He put it in terms that were quite kind to me, saying something along the lines of "Shawn carries this show every night, and tonight he gave out. Couldn’t you tell? Halfway through the first act, he lost the energy and the drive, and the show fell flat because no one else was there to help him pick it up.”

My first thought was, "Yeah. Where were you all?” The suggestion had been made that perhaps the failure of the evening was not my fault. I was willing to accept 
that, but then I reminded myself, “They're not on stage as often. How can they be expected to be responsible for carrying this show? I'm the one who has to drive it through from beginning to end.” But the truth is that I was not the only one responsible for its success or failure, and in that moment, I realized that I was just as responsible for that evening's problems as my colleagues were. It had nothing to do with my lack of energy and loss of drive. It had to do with my concept of this show as all about me.

Once I realized that, I stopped moving from line to line to line, from my moment to my next moment to my next moment, and I focused on my acting partners, what they were saying, what they were doing, and Thoreau changed again. He finally came alive. It took a few nights for this to occur, but the genesis for it came from Dr. Harris's lecture and my realization that I was pushing my way through the play without allowing others their moments. When I settled into the role with a new mindset, I eventually let go of some of the preplanned moments, the fears of failure, and the need to move it forward at every second on my own. As a result, the play became more fun, more alive, and more energetic, without a drain on my resources and reserves. And it happened just in timethe week before we moved into tech rehearsals, when I most needed reassurance that the play would work. I think of the wasted time; had I only realized that I was blindly following my preplanned performance, not even acknowledging those around me as they should be acknowledged, I can only imagine how human and vulnerable Thoreau might have become throughout the rehearsal process, as frightening or uncomfortable as that might have been for the actor playing him. 


\section{Case \#4: Fear}

Fear is the bane of existence for many actors. It seems silly because to be able to get up in front of an audience to begin with takes a lot of courage in the minds of many laypeople. But there is a different kind of fear as an actor. I am not afraid of forgetting my lines. It happens, and with luck and support from others in the cast, we cover the errors, perform the scene, and move on. A massive fear of failure is involved, though. As I told my English students at Auburn, writing is difficult and dangerous and scary. They turn in crafted papers to a teacher or even to peers for review, and then they have to receive and respond in some way to criticism. Even the most kindly-offered criticism can hurt, especially when dealing with writing. A creation is just that, something someone has created. It did not exist before. Suddenly someone is going to proclaim whether or not it should even exist now, and this brings up all sorts of personal issues. The urge to create and the ability to do so are god-like, and whatever criticism arises in response to the creation strikes directly at ability and talent when it comes to writing.

I believe this is true to an even greater degree in acting. A writer pours her creative energies onto a page, organizing, thinking, arguing, and sharing ideas and information. Then, typically, the reader and judge assesses the paper, joining the author at a later date to respond to the work. The writer has time to let the work go, and the responder has time to plan how to phrase comments judiciously. Acting is much more 
immediate. I often tell people that I act because the only time I can ever hear my two favorite sounds—uproarious group laughter and utter and complete silence—is when I act. My fear is that I will hear those sounds at inappropriate times. I may begin Hamlet's soliloquy “To be or not to be ....” only to be interrupted by group laughter, or I may deliver a fool-proof comic line to the sound of silence. It is concern over these moments that limits me and builds a fear that is strong enough to quell my ego.

Not only is acting more immediate than writing, but the scale can be much greater, especially during the initial learning stages. How many people actually read that freshman composition paper, and of those who do, how many talk about it months after the fact? With acting, it happens all the time. I remember being in a Wal-Mart in Auburn, Alabama, one evening, nine months after I had played Charlie Brown in You're a Good Man, Charlie Brown for Small Time Outreach Productions, the local community theatre. I traveled aisle by aisle, placing my necessities in the shopping cart, and I soon noticed a strong man in camouflage following me throughout the store. I had no choice but to try and lose him, so I did. Sneaking through the checkout, I thought I had succeeded in doing so, only to discover him waiting by the exit. “Aren't you that Charlie Brown?” Yes, I suppose I am that Charlie Brown, for the camouflaged man at least.

Acting carries a burden with it—-the responsibility of being the character portrayed. I hate to think that perhaps my Charlie Brown and my Henry David Thoreau are the same character. In the end-of-the-semester evaluation after Thoreau, Professor Vandenbroucke wrote:

I know him so well by his third year that there's the kind of familiarity one has being around a company of actors—and the attendant cognizance of particular 
traits and habits. Shawn can always be counted on to deliver, but I'd like to see him go further in transforming himself physically and vocally from production to production.

First of all, this comment does not indicate that I do not transform myself; it merely expresses the speaker's desire that I do that to a greater extent. Am I capable of doing this? In reality, the answer is "YES," but at times, I sense the very strong "NO.” This is caused by fear. It can be awfully frightening performing on that stage, especially if the security blanket is left in the rehearsal space.

I go to great lengths to justify why I do not work more fully at transforming myself. One of Dr. Frye’s initial comments ("Because he’s a good musical theatre performer and knows what works there, he sometimes relies on what he knows will work") becomes a source of defensiveness. I wonder what is so wrong with relying on what will work. Is not bad theatre and acting something that does not work? Are those failures often born out of taking some kind of risk? If so, why take risks? Why not do what will work and thus offer a strong performance? And if, as Professor Vandenbroucke says, I "can always be counted on to deliver" (a word that, to me, means perform the role well), what need is there to "go further in transforming [myself] . . . from production to production”?

In some sense, these questions are facetious. Many of the top-notch actors are revered for their ability to disappear in a role, to adopt new mode of communication, vocally and physically. The better an actor is at such work, the greater he or she is considered. But for every "great" actor who excels at altering his or her person when acting, there is another who does not alter himself. This actor I will call popular. Many 
popular actors create characters that are so based on their on personalities, their own style of acting, they become the same in every role. They win their audiences and maintain their careers by delivering every time, even if what they deliver does not change from performance to performance or role to role. They exude an energy that is enjoyed and appreciated by the vast majority of an audience and critiqued as "the same old thing” by a smaller portion of that audience.

I paint this dichotomy in black and white not because I believe it is either, but simply because I tend to be good at reducing things to black and white terms, as I have long ago noted. I think neither end of the spectrum applies to me, as I am capable of playing vastly different roles (from Creon in Antigone to a singing Russian dog in The Musicians of Moscva, for example) and creating very different physical and vocal patterns for each. But can this and should this be done with every role?

I suppose I am dealing with two separate questions, one considering ability, the other considering desire: (1) Can and how do I expand my repertoire of characters as an actor? And (2) Do I want to? A stronger question underlies them both: Do I have the guts? I definitely have the ability to push my vocal and physical transformations further. My classes at the University of Louisville truly have prepared me to do that. But I do not know if they have encouraged me to do that, and those are two separate issues. I feel prepared to transform more fully because I have the tools with which to begin a transformation—I know about body centers, vocal resonators, speech patterns, and movement patterns. I know how to alter these things on my body. This actor, however, is often terrified to do so. I might look foolish; I might drop the physical transformation for a moment and reveal the façade I have created. It may seem odd to conceive of an 
actor afraid to transform. After all, that is what acting is-the transformation of an actor into a character. Rarely are they intended to be the same.

However, a transformation takes great self-confidence to begin with, which I do not have and often make up for with my egotistical mental meanderings. ${ }^{6}$ The persona I have crafted for the stage is lively, intense when necessary, certain, and energetic. This persona works with minor alterations for a vast array of characters and types, and I have thus far been successful using it. My professors, however, are quite correct in desiring fuller transformation, which would open me up to playing a grater array of characters. The difficulty is that this persona is comfortable and safe; it reveals the things about me as a person that I do not mind revealing and carefully disguises those I do not wish to share.

A few weeks after Thoreau closed, Brian Martin, a classmate and colleague, spoke with me. He was very impressed with my performance, and (though Brian is as fond of hyperbole as I am) he claimed that was one of the finest performances he had seen at $\mathrm{U}$ of $\mathrm{L}$. Yet his words did not end there. He made a cryptic comment that I only partially understood, saying that if I were to embrace all of me, be confident in all of me, and let myself be, no one could stop me. I would blow the roof off the theatre. It took me many weeks to begin to understand that comment as a serious and useful piece of advice, but I believe I have begun to do just that. In order to embrace the transformations I am capable of undergoing, I must accept myself, and in accepting myself, the fear diminishes. Of course, this is a problem that could take years of analysis and therapy.

\footnotetext{
${ }^{6}$ Ego and confidence are not the same thing here, but I'm loathe to alter this phrasing, as I find myself making a case that should become clear in the conclusion.
} 
Thoreau terrified me. I loved every minute of it and felt confident that the show was strong, but I was not sure I could make Thoreau work. In the end, I did. Perhaps not as a Thoreau distinct from Shawn, but nonetheless a Thoreau that worked on stage. Driving to the theatre on opening night, I began to cry. I could not figure out what it was - a fear of failure, a sense that I had already failed, the pressure of such a large role, sorrow that the show was finally opening and the wonderful nights I had spent with my colleagues would soon be gone. Perhaps it was the fear that what I had originally dreamed would not be so stunningly wonderful. But that fear quickly diminished, and I turned my attention to the work ahead. Opening went well, but it was a night I needed to prove to myself I could do this role and this show. Once that fear was assuaged, the remaining performances brought partial standing ovations (a signal that, despite my appreciation of it, no longer seems to mean what it once did) and, more importantly, a greater sense of joy in living the life of this character for a few hours. 


\section{Conclusion: A Balanced Palate}

As a child, I dreamed of several different occupations when I grew up—-teaching, working as a zoo veterinarian, being an astronomer-but the dream that always stuck with me was writing. During my senior year of high school, much to the dismay of my science teacher, I chose to concentrate on English and made plans to major in it in college. As I analyzed it, this was a move that made me happy and acknowledged the voracious reading I did as a child and the voracious writing I dreamed of and piddled at doing. Every afternoon after elementary school, I played in my backyard, creating stories of the Kid Detectives, a group of “super-power” youths who solved mysteries. There were seven (all named after friends from school) each with an amazing "power”- one could run fast, another was strong. I was smart. Day after day, I would enact story after story, sometimes using the same story for days at a time, reenacting it until it was the most interesting I could make it—full of suspense and adventure and excitement.

And then I would attempt to write it. I would sit at my old Apple IIE computer

and type out a few sentences, then find myself stuck. So I would try another technique. I would force myself to write a page a day. Sadly, these would always be awful (I now realize that I was falling into the trap of telling page after page, instead of showing it). So I would try to record them on audiotapes to be transcribed later, but these turned into 
rambling messes, as I attempted to narrate the mighty stories, tethered in one spot by the power cord of a tape recorder.

So the stories were never written. Nonetheless, I turned out to be a good writer when I applied myself, and I traipsed off to Belmont University in the fall of 1999 to become an English major and seek my fame and fortune as a writer. I majored in English, then went on to get my MA in it at Auburn University, but all the while I did theatre. Then, I realized that English, despite my early interests, was not so interesting anymore and that theatre was my deeper passion, so I applied and auditioned and was accepted to the University of Louisville.

I knew I wanted to be an English major, and I pursued it with a narrow-minded focus and energy. I was good, won several essay contests, received honors for my English work, and remained in that field for fear of possible failure in a new discipline (theatre) and a new approach to a new kind of work. There I have summed up my acting: I was a strong intellectual, proud of my abilities, energetically pursuing my planned and chosen field, and afraid to switch to another less-certain one. All of the strengths turned weaknesses I discovered in the process of performing and analyzing my thesis performance have long been in place, long serving as strengths disguising weaknesses.

I began this thesis by discussing my desire to be a more transformed actor: “Clearly stated, I feel that I could be a more successful actor if I spent more time exploring (physically, vocally, mentally, and emotionally) whatever text lies before me and challenging myself continually to find new things in the play and to give those alternative choices more serious consideration as I create a character.” The passage below quickly followed this claim in an early thesis draft: 
These issues will provide the substance for the "Introduction" to follow. As I write these words, I have not yet begun rehearsals for my thesis show, The Night Thoreau Spent in Jail, written by Jerome Lawrence and Robert E. Lee, directed by Bert Harris. Still, in this "Introduction," I will set forth the goals I am setting for myself as an actor, considering them in enough detail, I hope, to make them clear to the numbers of readers my thesis will no doubt lure, as well as to propose possible means to achieve these goals. Then, as rehearsals begin, I plan to keep a detailed journal that will allow me to assess daily discoveries, progresses, and setbacks. Once the show is over, I will look back upon these journals and write the remainder of my thesis, assessing how well I managed to succeed or how frightfully I failed at achieving the goals I will shortly set forth. This is my plan, so let me begin.

My thesis role in the terms I set forth above was a failure. I am tempted to say complete failure, but this would be both incorrect and disrespectful to my director and fellow cast members who helped me move beyond some of my tendencies.

For many months, I thought that I would begin my thesis with this sentence: "I am lazy.” This would no doubt surprise those who know me; I do not think that most of my acquaintances would consider me lazy. Yet in a way, that opening would still be appropriate. For example, though I claimed in my original introductory remarks that "I plan to keep a detailed journal that will allow me to assess daily discoveries, progresses, and setbacks,” I never kept a journal. Instead I have a few scribbled notes in my script relating to big moments of epiphany and difficulties encountered during the rehearsal period—hardly the “detailed journal” I had planned.

Likewise, my earliest conceptions of what a thesis should be have been demolished. I found no guidelines for the style, content, or length of a thesis written to fulfill the requirements for an MFA in Theatre Performance at the University of Louisville. From the outset this worried me. If there were no specific requirements, how would I write the best one ever? How would I plan? How would I energetically follow 
the plan to a stunning conclusion? And what would keep me from the fear I felt as I stared at a blank computer screen?

It may seem as though I have made my point, but I have not done so fully. I could not have done so yet because it took an analysis of the frequently-referred to "strengths that seem weaknesses” in my acting to discover this point: all my strengths are strengths for a reason, and I should use them as a combined force to counterbalance each other and subvert the weak tendencies to which they individually lead. My ego must be mitigated with fear; my intellect with energy, and vice versa. My ego assures me, despite fears, that I can do the work before me well, and my energy can be used to slow down the intellect.

Each strength is fine in itself, but what is done with that strength can transform it into a weakness. The ego is important; it gives confidence and security, as well as a drive to create and share a unique, individual approach to whatever role I am facing, but when the ego leads to blind, isolated work, without consideration of others involved, the ego becomes bad. When this occurs, a reminder of the fears involved in the project can zap that ego and deflate it so that cooperative work can occur more effectively. The opposite is true, when fears beset me, I can rely on my ego; I can remind myself that I am prepared for the project, the task, and the new demands I face. Buoyed by that thought, my ego allows me to face them more bravely and do the necessary work without worrying and stressing. My intellect, so deceptively thorough, is a stumbling block as well. I miss things, or I fail to interpret a script as completely as necessary. If I use my energy to force my intellect to delve more deeply, rather than more broadly, I may discover all the holes that have heretofore plagued my work. And my intellect must temper my energy, 
acknowledging unanswered questions and not allowing my own drive to push past them so quickly.

I have not written a typical thesis. Many students include an analysis of class work, a complete description of the rehearsal process, and a thorough record of each performance. Nowhere have I seen this required, so I have written a thesis that avoids these questions for several reasons, not the least of which being that I agree with Professor Tompkins, who argues that the value of a course may not be recognized for years. To that end, I am attempting to withhold judgment and analysis of my coursework. Likewise, I have attempted to avoid answering some of the questions I pose in the various cases I have covered. By doing so, I hope I have begun to implant a new approach to acting through my writing.

Not all answers must come right away. Sometime it is better to leave some questions unanswered for as long as possible. I have touched on the rehearsal process for my thesis show, most importantly what I learned during it, and a video record exists of my Saturday evening performance in Thoreau. Far more valuable to me is this attempt to understand the biggest criticisms I receive on a regular basis, to determine what causes these flaws in my work, and to propose ways in which to solve them. I have the tools I need, and I have the ability to gain the trust of my fellow actors. I must now seek opportunities for artistic growth by stretching myself, even to the point of failing. In this process of stretching and risking, I must be prepared to relinquish control, to face fears, and to seek satisfaction in the work, not the acclaim of an audience. Hopefully this analysis of my strengths turned weakness turned strengths again will help me to do just that. 


\section{Epilogue: Four Months Later}

My first opportunity to implement the approach I describe in the previous chapter came roughly a month after Thoreau closed. I auditioned for Tom Stoppard's The Real Inspector Hound and was cast as the critic Moon. Having performed as Birdboot in this play before, I was familiar with the script and ready to tackle a new character. Moon would serve as my first role after the experience of Thoreau, and I wanted to see how my approach both to creating the role and to the rehearsal process would change: "Clearly stated, I feel that I could be a more successful actor if I spent more time exploring (physically, vocally, mentally, and emotionally) whatever text lies before me and challenging myself continually to find new things in the play and to give those alternative choices more serious consideration as I create a character.” I even proposed ways to achieve these goals: “All my strengths are strengths for a reason, and I should use them as a combined force to counterbalance each other and subvert the weak tendencies to which they individually lead. My ego must be mitigated with fear, my intellect with energy, and vice versa. My ego assures me, despite fears, that I can do the work before me well, and my energy can be used to slow down the intellect.” As I write this epilogue, The Real Inspector Hound has been over for only two weeks, and I am in a position to assess its success in the terms I have proposed above. 
To do so, I must consider what I expected the "new process" to be. I expected it to be radically different, from beginning to end, filled with constant questioning and marked changes in my presence on stage. I imagined that I would suddenly feel like more of an actor because of some grand transformation that would take place. And when I reflected on these goals during the process of rehearsal, I felt disappointed. No major change was taking place. I was failing to implement the plan I had made for myself to become a better actor, was growing disappointed in my work, and was becoming very self-conscious during rehearsals. So I stopped. I dropped all of the preconceived ideas of how this would be different; I ceased worrying that Moon was not so significantly different from Shawn, despite the fact that this was my goal. I was at a loss how to proceed.

I turned to my thesis to discover that gem of accidental thought that had spilled out on paper and revealed the mysteries of becoming a better actor. I did not find it. I sought hints from other places and discovered nothing of practical value. Finally, I reread some advice offered via email by a former director, Robert Caprio. I had worked with him at East Carolina University the summer before Thoreau, and at the end of the summer, I had asked him for any advice or suggestions he might give me to encourage my growth as an actor. He responded:

All I will say is trust your instincts ... you have good ones when you use them. But that's a common malady in young actors, trust (such a little word, but a tough one to execute); in other words, don't be afraid to "take a swing at the ball" . . . keep returning to the text when you work, you'll never know what you'll fine, and continue to dig, dig, dig. . . . Texts are like prisms: each time you look at them you see a different color.

I did not trust my instincts, that is certain. With every rehearsal that did not go as I had hoped, planned, or expected, I doubted my instincts even more. More importantly, 
though, I realized that the answers I sought lie in the texts, and I had to use both my strengths and weaknesses to discover them and bring them to life. Already, however, I recognized a potential trap. I reminded myself, "Not all answers must come right away. Sometime it is better to leave some questions unanswered for as long as possible.” Armed with this reminder, I still faced a few difficulties. My director for this production had very specific images in mind. He envisioned precise physical and vocal choices, even line readings that he felt would make a given moment as funny as possible. I found it difficult to explore my abilities as an actor within such a rigid framework and was growing highly frustrated and annoyed. Then I recalled similar experiences with another director. In that instance, I had given up, played the role as precisely as I could to imitate what he wanted. Here was an opportunity to find ways of working within a framework to give the director what he needed and create what I sought.

At our fourth rehearsal, the director worked solely with the characters of Moon and Birdboot. The first thing he did was to establish a physical vocabulary: how they would sit, what gestures they would make, in what manner they would watch the playwithin-the-play. This process revealed two things to me. First, here was a very precise roadmap, something my intellect always yearns for, that would allow me to choose consciously, to rehearse, and to perform physical actions that may or may not be Shawn actions. Moon crosses his legs tightly and sits up very straight, physical movements that Shawn rarely, if ever, makes. Second, even in the director's very specific approach, I found myself able to make suggestions that he felt worked quite well. Though it seemed clear that he had specifics in mind, I was able to offer suggestions that, if nothing else, he could consider against his pre-conceived notions. I dedicated myself to that end. My 
intellect was appeased that it knew how to get to a new point, and my energy worked within the framework to create new actions for Moon. My intellect and my energy worked together in a structured way to accomplish a different mode of behaving. I recognize that structure may not always be present in a rehearsal, but I feel more confident that I can provide a structure for myself that will allow for maximum exploration. I also feel that, when the rehearsal process is chaotic or impulsive, any work I have previously done within a structured framework remains intact and can inform the impulses that I follow in a rehearsal.

In this mix, I must also consider fear and ego, which played equally important balancing roles. Every evening, I would leave rehearsal drained, feeling I was accomplishing nothing. Part of this feeling resulted from what felt to me to be very slow progress on the character. In retrospect, I recognize that I was merely delaying setting anything in stone. As a result, I was afraid, which led to many moments of griping and complaining outside of rehearsal. With each eventual decision, though, my confidence, the good ego, returned. I was creating a character that had never existed before from rehearsal to rehearsal. Sometimes the character shifted based on a new recognition of his journey, sometimes based on a new physical choice, and sometimes based on the alteration of a single moment. But every time the character shifted, I found something different—perhaps only one piece of the puzzle, but a piece nonetheless.

Did I manage to create a Moon with a distinctly different presence from other characters I have created? I do not know. It is difficult to assess external perceptions. Moon felt different. I did not like him, and I have never not liked one of my characters before. He was too smug in everything he did and said and in how he did and said those 
things. What I do know for certain is that I made choices with Moon that I had not made before, and eventually I became less concerned with how the audience would respond to Moon and more concerned with the creation of this character. The work I did on The Real Inspector Hound is, for me, the first step in implementing the lessons I learned from playing Thoreau and assessing my work on that role. I believe Moon was a success, and I look forward to more opportunities to explore increasingly challenging characters.

My biggest challenge now is to let myself fail. Earlier in this thesis, I wrote, "I do not feel that any of the work I have ever done has been disastrous.” Perhaps it is time that it is so. Only by taking risks that might lead to failure can I move toward a higher plateau with my acting. Once I am there, who knows what new challenge will lie ahead? Acting is a continual growth process, within each role and between each show, and I must be open to the challenges I will face, recognize them, and meet them head on. 


\section{Works Cited}

Freud, Sigmund. “On Narcissism.” 1914.

Harding, Walter. The Days of Henry Thoreau. New York: Alfred A. Knopf, 1965.

Lawrence, Jerome and Robert E. Lee. The Night Thoreau Spent in Jail. New York: Samuel French, Inc, 1972.

Sophocles. Antigone, adapted by Steve Schultz. University of Louisville Theatre Arts Department, revised 2003.

Stoppard, Tom. The Real Inspector Hound. New York: Samuel French, Inc, 1968. 